\title{
Poverty and the Law of Child Custody
}

\author{
Herma Hill Kay* and Irving Philips**
}

7 HE RELATIONSHIP OF A NATURAL PARENT or parent-surrogate to his
children is a vital human relationship which has far-reaching implications for the growth and development of the child. It becomes the duty of the law to impinge upon the parent-child relationship at some of its critical points: divorce, separation, or death of the parents; delinquent behavior of the chvild; abuse or neglect of the child; and adoption of the child. In all these cases, the law has ultimately only one response to offer: It has the power to remove the child from his present home, whether that be with parents, foster parents, relatives, strangers, or an institution, and place him elsewhere either temporarily or for the duration of his minority. This power is typically exercised by a judge in a court hearing involving the general question of child custody, although the hearing itself may more particularly be concerned with a petition for divorce, adoption, guardianship, support, or a petition to make the child a ward or dependent child of the juvenile court. ${ }^{1}$

The general purpose of this article is to ask whether the law, in its approach to the child custody determination, hinders or advances the child's smooth progress toward social, emotional, psychological, and physical maturity. Our more specific purpose is to discuss the extent to which custody decisions are affected by poverty, including the problem of whether poverty itself creates new situations that may give riseperhaps inappropriately - to custody decisions. Fimally, we propose to raise again, hopefully from a different point of view, the general question of how custody decisions can reasonably be made.

I

THE LAW AND PRACTICE OF CHILD CUSTODX

The law of custody as developed in the opinions of appellate courts lends itself to vague, almost facile statement. Its Englislı origins may be traced to feudal notions of parental authority over the child's services

*B.A., 1956, Southern Methodist University; J.D. 1959, University of Chicago. Professor of Law, University of California, Berkeley.

* B.A., 1943, Oberlin College; M.D., 1948, University of Tlinois. Associate Clinical Professor of Psychiatry, University of California School of Medicine, San Francisco. Supervising Psychiatrist, Children's Service, The Langley-Porter Neuropsychiatric Institute.

1 It has been remarked by a trial court judge experienced in family law matters that "the factors which judges consider in determining custody of children are generally the same in whatever legal form the question is presented." Weinman, The Trial Judge Awards Custody, 10 Law \& Contearp. Prob. 721, 724 (1944). 
and the wardship rights in his marriage and lands. ${ }^{2}$ At common law, the father had an absolute right to the custody of his legitimate children $;^{3}$ the mother had no right even to visit her children without their father's consent. ${ }^{4}$ The American colonies also recognized a paramount right to custody in the father, but statutes have been enacted in virtually all states that place the father and mother on an equal basis when they dispute custody between themselves. ${ }^{5}$

As a consequence of the historical emphasis on parental rights, many courts distingnish the right to custody of a natural parent from that asserted by all other persons, including close relatives. Thus, im the context of divorce and guardianship ${ }^{6}$ cases, courts typically distinguish between disputes involving parent and nonparent contestants, and those involving only parents. In the former situation, many states recognize a so-called dominant parental right doctrine that requires a showing of parental unfitness before the child can be awarded to a nonparent. ${ }^{7}$ The burden of proving a parent unfit is a heavy one; consequently, cases where a finding of unfitness is upheld on appeal tend to be illustrations of extreme behavior. ${ }^{8}$

2 Sayre, Awarding Custody of Children, 9 U. Cerl. L. REv. 672, 674-75 (1942); tenBroek, California's Dual System of Family Law: Its Origin, Development, and Present Status, 16 Stan. L. REv. 900, 925 (1964). For a statement of the modern English law, see Stone, Parental Custody of Infants in English Law, in Society of International \& Cosparative Law, Spectai Publications 10, at 18-22 (1966).

${ }^{3}$ Illegitimate children had no assured right of paternal custody at common law. Kay, The Family and Kinship System of Illegitimate Children in California Law, 67 AMERICAN ANTHROPOLOGIST 57, 58-59 (1965).

42 Arasstrong, Calmornta Fandrx Law 953 (1953). The mother's custodial right was not made equal to that of the father until 1925. Guardianship of Infants Act, 1925, 15 \& 16 Geo. 5, c. 45.

52 Armstrong, op. cit. supra note 4, at 954; Madden, Persons and Domestic Retations 369-72 (1931).

${ }^{6}$ The question of guardianship of the mentally ill or mentally retarded child poses quite different problems. See Levy, Protecting the Mentally Retarded: An Empirical Survey and Evaluation of the Establishment of State Guardianship in Minnesota, 49 MINN. L. REv. 821 (1965).

${ }^{7}$ See Armstrong, op. cit. supra note 4, at 993-1018 and cases there cited; MaddeN, op. cit. supra note 5, at 372-73; Bronson, Custody on Appeal, 10 Law \& Contearp. Pros. 737, 740-41 (1944); Foster \& Freed, Child Custody, 39 N.Y.U.I. REv. 423, 425-27 (1964); Sayre, supra note 2, at 676-77; Simpson, The Unfit Parent, 39 U. DET. L.J. 347 (1962); tenBroek, supra note 2 , at $919-27$.

${ }^{8} \mathrm{~A}$ recent comprehensive survey of the appellate decisions summarized the profile of the unfit parent: "To determine when a parent is unft, the courts consider several factors. . . . Among them are the moral character and emotional stability of the person who wishes custody of the child. A parent may, for example, be classified as unfit if he has been guilty of gross immorality or drunkenness, has been convicted of crime, has been cruel or violent towards members of the family, has been guilty of desertion, abandonment, or failure to support, has been mentally ill, or bas stipulated or contracted for a relinquishment of custody. 
In cases where each parent seeks custody of the child and no other person is involved, a finding of unfitness is unnecessary since neither parent enjoys as against the other a superior right to custody. ${ }^{9}$ The typical divorce case presents this situation. In such cases, the overwhelmingly accepted legal position is that the award of custody should be made by considering "the best interests of the child,"10 supplemented by a few simple rules of thumb such as the prevalent notion that young children should be placed with their mother. ${ }^{11}$ Courts are said to place their reliance on the following factors in determining the best interests of the child:

Among the factors considered by the courts are the social, spiritual, psychological, and economic conditions prevailing at the alternative environments. A child's physical and mental health is another factor which may dictate a custody award. . . .

Other factors ... have been the character of other persons in the home, educational and religious opportunities therein, and the type of lome and neighborhood. ...

In addition, the courts may weigh assumed bonds of love and understanding between the child and the contesting parties, the length and intimacy of their association, and the wishes of the child. The ages of the child and the parties, the attachment of the child to his environment, and the amount of time available for his rearing, have also been deemed relevant. Other persuasive factors include a desire to keep siblings together rather than to split custody and a feeling on the part of the court in some cases that a given claim for custody is not bona fide but a maneuver in a power struggle between the adversaries. Fimally there is a tendency to assume the local milieu is better for children than some foreign clime. ${ }^{12}$

These vague tests give virtually no guidance to the courts and satisfy none of the writers in the field. One particularly troublesome problem is the conflict between the tests themselves. Many a court has found itself

In such situations, there may exist both an element of parental unfitness and a danger of moral harm or bad example to the child." Foster \& Freed, supra note 7, at 427-28. By "gross immorality" the authors apparently mean adultery. Id, at 429-31.

See text accompanying note 5 supra.

10 See Ararstrong, op. cit. supra note 4, at 960-92 and cases there cited; MaddeN, op. cit. supra note 5, at 376-77; tenBroek, supra note 2, at 915-19. This test also applies where all the contestants are nonparents, at least if they have the same degree of relationship to the child. Guardianship of Hall, 200 Cal. App. 2d 508, 19 Cal. Rptr. 426 (1962) (the contestants were the paternal grandparents and the maternal grandparents). See also CAI. Prob. Code $\S \S 1405-07$; CAL. Crv. CODE § 138(1).

11 Foster \& Freed, supra note 7, at 436 ; and cases there cited at note 64 . This rule frequently finds its way into statutory expression. E.g., Cax. CIv. Cope $\$ 138(2)$.

12 Foster \& Freed, supra note 7, at 439-41. See also Comment, The California Custody Decree, 13 Start. L. Rav. 108, 110-11 (1960). 
in the unhappy position of having to award a child to its parents despite a finding that the child's best interests would be served by a placement outside the parental home, because the parent could not be proved unfit. Such a case was Stereart v. Stereart, ${ }^{13}$ decided by the Cahfornia Supreme Court in 1953. The husband and wife had divorced in 1949, when their son was eight years old and their daughter was six. By agreement, neither parent sought custody; instead, the children were sent to live with their father's sister and her husband. The agreement, made part of the court's decree, provided that neither parent was to visit the children for three months after the entry of the interlocutory decree of divorce and that neither parent should ask for a modification of the decree, unless the custodians died, for one year. The mother remarried in 1950, and in 1952 asked for a modification of the decree to permit her to have sole custody of both children. The father did not ask for custody, but opposed the mother's petition and urged that the children be left with their aunt and uncle. The trial court denied the mother's petition, but failed to find that she was in any way unfit to have custody. The Califorma Supreme Court noted in its opinion that a change of custody might entail serious emotional disturbances for the children,$^{14}$ but nevertheless thought itself forced by the dominant parental-right doctrine to reverse the trial court.

Many commentators believe that the dominant parental-right doctrine should be replaced by a broadened best-interests-of-the-child test so that the court's inquiry would focus on the needs of the child rather than the rights of the parents. ${ }^{15}$ Apparently this proposal has a better chance of being accepted in cases like Stewart where the child has been living with the nonparents for a substantial period of time before the parent seeks to regain custody. ${ }^{16}$

Even if the best-interests test were to replace the parental-right approach, however, the hard problem of finding out what the best interests of the child require would not be solved. Thus, in a recent case that has attracted national attention, ${ }^{17}$ the Supreme Court of Iowa upheld the Bannisters; maternal grandparents of a seven-year-old boy, in their refusal to return the child to his father. The father, Mr. Painter, had temporarily left his son, Mark, with the Bannisters following the sudden death of the child's mother and sister. Two years later, the father remarried and

1341 Cal. 2d 447, 260 P.2d 44 (1953).

14 Id. at 453,260 P.2d at 48.

15 E.g., Foster \& Freed, supra note 7, at 436-37; Foster \& Freed, Child Custody, 39 N.X.U.L. REv. 615, 626-30 (1964); tenBroek, supra note 2, at 926-27. But see Sayre, supra note 2 , at $677-85$.

16 See Foster \& Freed, supra note 7, at 436, and cases there cited at notes 60 and 61.

17 Painter v. Bannister, 140 N.W.2d 152 (1966) (Iowa). See Life, Nov. 4, 1966, pp. 101-02. A rehearing in Painter was denied on June 13, 1966. 
he and his second wife were anxious to make a home for the boy in California. The Bannisters, who had never approved of their daughter's marriage to the father and who disapproved of his way of life, refused to surrender the child. The father filed a petition for habeas corpus; the lower court ordered the grandparents to return the boy, but the Iowa Supreme Court reversed on appeal. There was no suggestion that the father was unfit to have custody of his son; his second wife was considered capable of providing able care for the child, and the mother's will had nominated Mr. Painter as guardian of the child. Despite these favorable factors, however, the court found that the best interests of the child demanded that he be left with the grandparents. The court's evaluation of the two lomes indicated that:

The Banmister home provides Mark with a stable, dependable, conventional, middle-class, middlewest background and an opportunity for a college education and profession, if he desires it. It provides a solid foundation and a secure atmosphere. In the Painter home, Mark would have more freedom of conduct and thought with an opportumity to develop his individual talents. It would be nnore exciting and challenging in many respects, but romantic, impractical and unstable. ${ }^{18}$

Muclu was made of the testimony of Dr. Glenn R. Hawks, a child psychologist, to the effect that the boy "has already made an adjustment and sees the Bannisters as his parental figures"; ${ }^{10}$ that any cliange of living arrangements at this point in his life would be detrimental to him; ${ }^{20}$ and that "the chances are very higll (Mark) will go wrong if he is returned to his father."21 Accepting the psychologist's evaluation that the child's most urgent immediate need was for security, the court made clear its belief that "security and stability in the home are more important than intellectual stimulation in the proper development of a child."22 This evaluation, in the absence of supporting empirical studies, would appear to depend on what kind of a child one hopes to produce: a decision that society normally leaves to parents.

The Iowa Supreme Court in the Painter opimion displayed an unusual willingness to substitute its assessment of the best interests of the child for that of the trial court without sending the case back for a new hearing; Many appellate courts do not attempt to discover from the transcript of events at the trial level whether the court wrongly assessed the best interests of the child. Thus, appellate courts have in effect discouraged

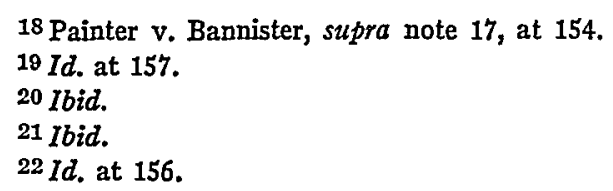


losing parties from appealing in all but the most flagrant cases by the uniform application of the rule that a trial court's custody decision will be reversed on appeal only when an abuse of discretion lias occurred. ${ }^{23}$ It may be doubted, however, whether trial courts, if left to the law's devices without special traiming or especially trained assistants, are in a better position to decide the custody issue than appellate courts. It is true that the trial judge has the advantage of seeing and hearing the witnesses, an advantage which slould not be taken lightly. Even so, a trial judge's list of factors considered in deciding custody matters differs only slightly from those discovered by Foster and Freed in their study of the appellate cases. ${ }^{24}$

Finally, a word must be said about the inodification of clild custody decrees. Professor Foster lias stated the law of inodification in a paragraph: "Where modification is souglit there must be a clear showing of a substantial change of circumstances since the time of the award under attack. In addition, it must be demonstrated that new circuinstances require a cliange of custody in order to promote the best interests of the child." ${ }^{25}$ Because a custody decision is never final, parties who will not accept defeat may engage in repeated modification hearings. Even if the local court makes plain that it will not listen patiently to repeated petitions, the parent of means may remove the child to another state, in defiance of the prior decree, there to begin again. The position of the custody decree in the conflict of laws is dangerously unsettled in view of the liuman einotions involved; ${ }^{26}$ currently attempts are being made, albeit from different points of view, to work toward a sensible solution for the "interstate child." 27

How, then, should the custody decision be made? On the one liand,

23 Bronson, supra note 7, at 740; Stack v. Stack, 189 Cal. App. 2d 357, 372-73, 11 Cal. Rptr. 177, 188 (1961) (the court commented that appellate courts have "almost completely abdicated in this field in favor of the trial courts").

24 Compare Weinman, supra note 1, at 734-35, with note 8 supra.

25 Foster \& Freed, supra note 15, at 623.

26 The confusion has been created mainly by the United States Supreme Court's inability to agree upon a clear position as to the relationship between the Due Process and Full Faith and Credit Clauses of the Federal Constitution as those Clauses apply to child custody judgments. See Hazard, May v. Anderson: Preamble to Family Law Chaos, 45 VA. L. REv. 379 (1959).

27 See, e.g., the opinion for the Court by Traynor, J., in Sampsell v. Superior Court, 32 Cal. 2d 763, 197 P.2d 739 (1948); Restatenent (Second) Confuct or Laws, \& 117 (Tent. Draft No. 1, 1953) ; Currie, Full Faith and Credit, Chiefly to Judgments: A Role for Congress, in 1964 Supreane Court RevIEw 89, 109-118 (Kurland ed.); Ehrenzweig, The Interstate Child and Uniform Legislation: A Plea for Extralitigious Proceedings, 64 MICH. L. REv. 1 (1965); Ehrenzweig, Interstate Recognition of Custody Decrees, 51 MICH. L. REv. 345 (1953); Ratner, Legislative Resolution of the Interstate Child Custody Problem: A Reply to Professor Currie and a Proposed Uniform Act, 38 So. CaI. L. REv. 183 (1965). 
parents are warned by a psychiatrist not to leave the decision to the courts $;^{28}$ on the other, courts are admonished by a Supreme Court Justice not to leave it to the parents. ${ }^{29}$ As in so many other areas of family law where there is disagreement on the goals, the first steps are nevertheless agreed upon. Necessary reforms begin with special instruction in the law schools so that law students - future judges - can be made aware of the special skills needed for handling human problems. ${ }^{30}$ In the absence of special training; the trial court judge must rely on others to place at his disposal the skills and insights of behavioral science that may render more precise and reliable the vague standards of the law. ${ }^{31}$ How is this union of law and science to be accomplished? The traditional method, available to those who can afford it, is to call psychiatrists, psychologists, and social workers as expert witnesses. Such testimony is frequently helpful to the judge; but in too many cases the opposing side also has its psychiatrists, and the "battle of the experts" so long deplored in criminal law makes its appearance in the civil case. For example, ${ }^{32}$ Mrs. $X$, a divorcee who was suffering from a severe emotional disorder, had recently been discharged from a private sanitarium. She was seeing a physician for continued psychiatric therapy. Custody of her children had been originally awarded to her, but changed to her husband. She retained hberal visitation rights. The children were being cared for by a housekeeper in the father's home. The father, a busy attorney, traveled a great deal and rarely had time to spend with the children. They complained that the mother often derided the father and insinuated to them that he was a homosexual. She, on the other hand, openly carried on affairs with various men while the children visited in her home. The mother decided that she wanted the children back and filed a petition for modification which was opposed by the father. She was supported by her own psychiatrist and two other psychiatrists who testified to her fitness to resume custody. Their evidence was supported by psychological tests indicating that the mother "had the ideal qualities for assuming custody of her children." The father produced evidence from a psychiatrist who had seen the mother while she was hospitalized and from another psychiatrist and a social worker who had

28 Despert, Chitdren of Divorce 189-91 (1962).

29 Ford v. Ford, 371 U.S. 187, 193 (1962) (Opinion for the Court by Mr. Justice Black).

30 See Levy, The Perilous Necessity: Nonlegal Materials in a Family Law Course, 15 J. LEGAT ED. 413 (1963). Three casebooks now on the market combine legal and nonlegal materials for family law courses: Foote, Levy \& SANDER, Cases on FAMIII LAW (temporary ed. 1966); Goldstend \& Katz, The FandrI and The LaW (1965); and Harper \& SKOLNICK, Problems of THe FaMIII (Rev. ed. 1952).

31 See Foster \& Freed, supra note 7, at 441-42.

32 Cases in this article which are not cited to a source are from the personal files of the authors. 
seen the children. These witnesses told the court that the children needed their father and that the mother had a severe character disorder that would be disruptive to the continued growth of the children. The court, unable to decide the question on the basis of the conflicting testimony, requested an additional psychiatrist to evaluate the total family situation. Finally, the mother resolved the dilemma herself by becoming ill and having to be readmitted to the sanitarium.

One psychiatrist has recently suggested, as an alternative to the courtroom battle of experts, that the parents agree to divide custody between themselves, cooperating in making the necessary decisions, and leaving their differences to be resolved by an appointed committee consisting of "a pediatrician, a child psychiatrist or child analyst, an educator and/or an impartial lawyer or clergyman."33 The committee would be assisted by a "trusted adult-ally outside the family circle with whom the child can talk in confidence"; the adult-ally would have "technical training and experience in the highly specialized art of histening to children," and would, as part of his function, "inform the committee of what the child thinks and feels, thus providing a sound basis for the committee's decisions."34

Assuming, as seems to be the case, that the committee's decision would be binding upon the parents unless a reviewing court determined that it would not serve the best interests of the child, ${ }^{35}$ the proposal nevertheless appears to have serious drawbacks. Thus, no provision is made for the committee to understand the family's day-to-day problems, let alone their psychopathologies, to ensure expert knowledge on which to base decisions. Social acquaintance with the spouses prior to divorce would not serve this purpose adequately. Provision for consultation with the spouses after the divorce, even if acceptable to them, would probably render the device expensive enough to prevent most parents from attempting this solution. Finally; one should not assume easily that a committee is any more capable that an individual of remaining "impartial"30 and free from the hostility that often characterizes divorced couples. Matters as complex as intrafamilial relations are not resolved by a commitiee.

A preferable approach is the establisliment of family courts "staffed

33 Kubie, Provisions for the Care of Children of Divorced Parents: A New Legal Instrument, 73 YALE L.J. 1197, 1198 (1964).

34 Id. at 1199.

35 Note, Committee Decision of Child Custody Disputes and the Judicial Test of "Best Interests," 73 Yale L.J. 1201, 1204-05 (1964); Note, Domestic Relations, New York Court Approves Use of Arbitration in Custody Disputes, 33 FordHAar L. Rev. 726 (1965) (discussing Sheets.v. Sheets, 22 App. Div. 2d 176, 254 N.Y.S.2d 320 (1964)).

30 See Diamond, The Fallacy of the Impartial Expert, 3 Arcerves of Cramarar PsychoDYNAMTCS 221 (1959). 
with experts able to make a full-scale investigation and produce a report for the judge. ${ }^{237}$ The true family court is commonly defined to have three major characteristics. ${ }^{38}$ First, the court is headed by a specialist judge and has an integrated jurisdiction over all legal problems that confront the family in conflict. This characteristic means three things. It means that the family court should be a simgle court, if possible located in a single building. It can either be a special court or a court of general jurisdiction with specialized duties, such as the present juvemile and probate courts. It means also that the court should have a judge with a permanent, or at least lengthy, appointment to enable him to develop specialized skills in handling family problems. Finally, the specialized court should handle all legal problems of the family in conflict. Thus, it should handle:

abandonment (of child, pregnant woman, spouse), abuse of child, adoption, alimony claims, annulment of marriage, assault and battery (intra-familial), bastardy, consent to marry, contributing (to delinquency, dependency, or neglect), custody of children, declaratory judgments, dependency of children, divorce, filiation proceedings, habeas corpus (intra-familial, husband and wife), juvenile delinquency, neglect of children, non-support (of child, parent, spouse), parent and child, partition of real estate (intra-familial), separate maintenance, visitation of children. ${ }^{39}$

The second major characteristic of the true family court is that it is assisted by a staff of specialists, trained in social work, psychology, psychiatry, and sociology. Information gathered about the court's "clients" would be kept in central files and be available to the court and its staff each time a family member appears in court. Finally, the true family court is a therapeutic institution: It exists for the purpose of providing help for families in trouble and employing the resources of the community to that end.

It remains only to be said that the family court, as thus described, is a movement rather than a reality. The court that comes closest to the three characteristics is the Domestic Relations Court of Toledo, Ohio,

37 Foster \& Freed, supra note 15 , at 627.

38 The text material on the family court is drawn from Kay, The Family Court, April 8, 1964, an unpublished address delivered in San Francisco and circulated in mimeograph form as Appendix $\mathrm{C}$ to Hearings on Domestic Relations, A Synopsis of Testimony before the California Assembly Interim Committee on Judiciary, Subcommittee on Domestic Relations, Sacramento, Californic, Aug. 113-14, 1964. See also Alexander, The Therapentic Approach, in The Untversity of Chicago Law School Conference on Divorce 51-54 (Conf. Series No. 9, 1952); Despert, Chmdren of Divorce 221-36 (1962); Flexner, Oppenhteicar \& Imenroot, The Camd, The Fammy, and The Court, ChIIdren's Bureau Publication No. 193 (U.S. Dep't of Labor, 1939); Bodenheimer, The Utah Marriage Counseling Experiment: An Account of Changes in Divorce Law and Procedure, 7 UTAH L. REv. 443 (1961); Symposium on the New York Family Court Act of 1962, 12 BUFraLo L. Rev. 409. (1963).

39 Alexander, The Family Court-An Obstacle Race?, 19 U. PIrr. L. Rev. 602 (1958). 
developed largely under the leadership of Judge Paul Alexander. Most of the other so-called family courts in this country, however; do not meet the definition here proposed. In the main they are either essentially juvenile courts to which special powers have been added but which lack jurisdiction over divorce such as the New York Family Court, ${ }^{40}$ or they are divorce courts to which a reconciliation wing has been added but which lack jurisdiction over juveniles, such as the Los Angeles Court.11

\section{II}

\section{CHIID CUSTODY AND THE POOR}

An unspoken assumption of the discussion so far has been that when parents separate, they divorce; and that when they divorce, a court somewhere will award custody of the children. This assumption does not hold true for parents afflicted by poverty. Evidence has mounted swiftly that many parents lack funds to secure divorces and either separate by mutual agreement or one parent-usually the father-deserts the spouse and children. ${ }^{42}$ Legal Aid Societies typically either refuse to process divorces in such cases or agree to do so only under conditions not imposed by private lawyers on their paying clients. ${ }^{43}$ Spouses who have thus informally separated can establish new relationships only by illegal means. The number of families living together with one or both spouses married to others has become a serious problem in California. The concern of the

40 Thus, the criticisms of the New York system contained in Professor Paulsen's article, Juvenile Courts, Family Courts, and the Poor, this symposium, do not apply to a true family court. Indeed, one of his major criticisms, that the New York court has become almost exclusively an institution of the poor, is directly related to the fact that the court does not handle divorce cases. Even thougb the upper and middle classes may be able to keep their delinquent children out of juvenile court, a court having divorce jurisdiction would process all classes. New York has recently enacted a new divorce bill (effective September 1, 1967) which broadens the grounds for divorce and provides for concilliation commissioners to decide wbether marriage counselling is necessary, and for guardians to represent the interests of children involved in the divorce. Zion, Divorce New York Style, N.Y. Times, May 1, 1966, Sec. E., p. 6, col. 2. New York thus is apparently to have both a "Family Court" and a separate "Concilliation Court" to deal with family problems.

41 Professor Foster has recently described and discussed the court systems which exist or were attempted in Ohio, Wisconsin, Utah, Maine, New Jersey, Los Angeles, Michigan, and New York. Foster, Conciliation and Counseling in the Couts in Family Law Cases, 41 N.Y.UL. REv. 353 (1966). On May 11, 1966 Governor Brown appointed a Governor's Commission on the Family to consider the creation of Family Courts for California. San Francisco Chronicle, May 12, 1966, p. 8, col. 1.

42 See, e.g., Foster, Common Law Divorce, 46 MnNo. L. Rev. 43, 57-59 (1961). See generally Weyrauch, Informal Marriage and Common Law Marriage, in SEXOAL BEHAVIOR AND THE LAW 297 (Slovenko ed. 1965).

43 Paulsen, The Legal Needs of the Poor and Family Law, in Conference Proceedinos on The Extenston of Legat Services to the Poor 18-22 (U.S. Dep't of H.E.W. 1964). The conditions referred to are mandatory attempts at marital reconciliation through agency counseling. 
State Department of Social Welfare was described in testimony before the California Assembly Interim Committee on Judiciary in 1964 by a representative of the Department:

[W] economic scale for whom divorce action is a luxury beyond their financial means. They are no less prone to family breakdown than members of other econonric classes but because they cannot afford the legal procedure of divorce, they must resort to the poor man's divorce, that is, separation or desertion. The real problem develops when, like people with conventional divorces, they decide to remarry and want to make the second marriage work. [After interruption for questions, Mr. Simmons returned to his text.] Forty-three per cent of AFDC [Aid to Families with Dependent Children] children born to parents who were not married to each other were actually members of such families in which the parents treated each other and their children in all respects as would a legally married couple. . . . We believe that some form of legal aid should be readily available to families where divorce is indicated on the basis of a social study and particularly to stabilize an existing second home and family for children. ${ }^{44}$

\section{A. Offer-of-a-Free-Home Cases}

The Department of Social Welfare, administrator of the AFDC program, encounters many other problems peculiar to the family law of the poor. One such problem formerly raised the child custody issue in a unique context. The States are required by the Federal Social Security Act to consider all income and resources available for the support of the child in determinimg his eligibility to receive aid. ${ }^{45}$ The California Act, in addition, provides that children who live in institutions and receive a "bona fide offer of a proper home" are thereafter ineligible for further aid. ${ }^{46}$ The State Social Welfare Board, in promulgating regulations for the administration of the program, interpreted the offer-of-a-free-home category to include offers made to all children receiving AFDC whether or not they lived in institutions. ${ }^{47}$ Thus, the Regulations and the imple-

44 Car. Assembly Interma Comar. on Judictary, Transcript of Proceedings on Domestic Relations 71, 92-92-93 (Los Angeles, Jan. 8-9, 1964). See also tenBroek, California's Dual System of Family Law: Its Origins, Development, and Present Status, 17 STax. L. REv. 614, 617-21 (1965).

4553 Stat. 1379 (1939), as amended, 42 U.S.C. 602 (a) (7) (Supp. I, 1965).

46 Cat. Werfare \& Inst'ns Code $\S 11264$. The section is virtually identical to former $\S 1524$, added in 1937.

47 In one case, the appellant was represented by counsel who questioned the Board's statutory authority to extend the offer-of-a-free-home section to noninstitutionalized children, but the case was decided without passing on this question. See $P$., Feb. 25, 1955. (The cases are confidential, CAI. WetFare \& INST'NS CODE $\S 108-50$, and are available only in the offices of the State Department of Social Welfare in Sacramento. Citations to Fair Hearing Appeals will therefore give only the applicant's initial and the date on which the appeal was heard before the Social Welfare Board.) 
menting Handbook sections required workers to decide whether a bona fide offer of a free home made by a parent, relative, or other person should be considered as a resource in determining the child's future status as a needy child. Regulation C-316, which was superseded in 1963, provided that: "Decision as to the eligibility of a child who is offered a free home by a relative, other person; or agency, is to be made on the basis of the legal, social, emotional, and financial security for the child in the lome offered as compared to his present home." ${ }^{28}$ To be sure, if the worker's decision was that the offer must be considered as a resource available for the clild's support, the resulting determination was merely that the child was meligible for AFDC support in its present home; not that the child's custody must be transferred to the person making the offer. ${ }^{40}$ Nevertheless, such a decision was obviously closely akin to a judicial assessment of whether the best interests of the child require its placement with the father or mother; and, indeed, a great many of the cases growing out of this Regulation were cases where the children were being maintained under the AFDC program in the home of the mother and the offer of a free home had been made by the father. Moreover, in many cases the practical economic effect of the termination of aid was the mother's inability to keep the child in her home.

Several important points are suggested by the offer-of-a-free-home cases that bear on the overall question of the supposed conflict between the use of public funds for private support and the right of individual recipients to be treated equally with nonrecipients. ${ }^{50}$ Thus, in several cases legal custody was awarded to one parent prior to the application for AFDC. The child, being supported by public funds in the home of the custodial parent, was then offered a free home by the noncustodial parent. In sucl circumstances, the termination of aid to the custodial parent might nullify the court order without a modification hearing. Equal treatment of recipient and nonrecipient families would thus appear to require that the court's custody award be protected by continuing the grant of

48 Cal. Dep't of Soclat Welfare, Manual of Poltcies and Procedures: Atd to FAMIIIES with Dependent ChIIDREN, C-316 (No. 31-35, May 1, 1957) (superseded by Rev. 495, Nov. 1, 1962). As the text indicates, this regulation was superseded in 1963 by a new one, which effectively disposes of the issue. Present C-316 provides that "Except as provided in W \& IC $\$ 1524$ [now \$ 11264, see note 46 supra] aid sball not be denied or discontinued for an otherwise eligible child who is offered a free home." During the years of its effectiveness, however, the old regulation $\mathrm{C}-316$ and its predecessor, regulation $\mathrm{C}-390$, accounted for approximately fifty Fair Hearing Appeals to the Social Welfare Board.

49 This point was made in the CAL. DEp'T of Soctax Wetrare, op. cit. supra note 48 , and is reiterated in the Fair Hearing Appeals cases. E.g., A., Jan. 25, 1962; T., March 20, 1958.

50 Sce McKeany, The Absent Fatrer and Public Policy in The Program of Aid to Dependent Cempren 37-40 (1960); Reich, Individual Rights and Social Welfare: The Emerging Legal Issues, 74 YALE L.J. 1245 (1965). 
public funds to enable the child to remain with the parent having legal custody. No such policy appears to have become official; the result of many of the appeals cases, however, enforced such a policy in practice. Thus, where the mother had legal custody and the children were supported in her home by AFDC; the Board tended to refuse to permit the withdrawal of funds to be used as a lever to force the mother to give up custody to the father, ${ }^{51}$ even in the face of an indication that the mother's home might be considered unfit. ${ }^{52}$ If, lowever, the father held legal custody and the children were supported by AFDC in the inother's liome, the cases were in conflict. In several cases the grant was continued: in two, because the father had not "actually exercised" his legal right to custody; ${ }^{53}$ in another, because his lrome was not immediately available for the child; ${ }^{54}$ and, in another, apparently because the worker thouglit the child was better off in the mother's lome..$^{55}$ In other cases, including one where the inother had deserted the family prior to reclaiming the children, ${ }^{56}$ the father's right to custody was enforced by terminating the aid. ${ }^{57}$

In cases where the parents had separated without obtaining a legal custody award, or where they had never been legally married, the offer of a free home was evaluated from the general point of view of the best interests of the child. A sampling of the cases presenting this problem indicates that the factors considered were not substantially different from the factors said to motivate courts in awarding custody ${ }^{58}$ Thus, in one

51 E.g., E., Nov. 15, 1962; J., Nov. 17, 1962 (mother had temporary custody); W., Sept. 23, 1960; S., April 23, 1954.

$52 D$., May 25, 1961. (petition alleging unfitness of the home had been filed in the juvenile court, but no action had been taken).

$53 M$., June 29, 1962. (record indicates that the father had asked the District Attorney to enforce his right to custody in September 1961); S., Feb. 25, 1955 (Although the father had legal custody, the boy was living with mother by agreement and Board did not wish to remove him from his high school where he was domg well and had many friends).

54 A., Jan. 25, 1962.

55 . ., Aug. 26, 1960.

$56 J .$, Nov. 15, 1962.

57 F., May 24, 1957; S., Oct. 21, 1955.

58 See text accompanying notes 12,24 supra. If the mother had the children in her home, AFDC was often continued to permit her to keep them, e.g., S., Sept. 22, 1961; S., Aug. 25, 1961, unless it clearly appeared that public policy would not be served by permitting the children to remain in her Lome, e.g., $J$., June 23, 1961 (mother had mine children by four different men; of the nine, three were in San Quentin and three others had juvenile records; father of the ten-year-old girl involved had married and apparently established a stable home). And see $G$., Oct. 18, 1956, where a Negro father had married a white woman and the Negro mother argued that racial mixing in the father's home would be bad for the children. The Board found that the evidence was insufficient to support the conclusion that the children "would have more adequate emotional and physical security" with the father than with the mother. 
case $^{59}$ the father and mother had been divorced without obtaining a custody order and the two children of the marriage, together with another child whose paternity the father denied, lived with the mother. She established a "stable relationship" with another man and had four children by him. The father, meanwhile, had remarried and was earning approximately five hundred dollars per month. He and his second wife offered a free home to the oldest child; a girl aged ten. The mother, now hiving alone with the seven children, wished to keep the girl at home. Although a careful evaluation of the father's home indicated that it was "a good one in terms of love, understanding and emotional and financial security," the Board decided to continue the AFDC grant to support the girl in her mother's home. The decision was based on the girl's attachment to her mother, her express desire not to be separated from her brother and sister, and because "we cannot consider that the home offered is a suitable substitute for her present home or that the care reportedly available to her in the home of her father and stepmother ... might adequately replace the emotional security that a mother can give her own children and which is essential to their well-being."

The offer-of-a-free-home device presented opportunities for antagonistic family members to express their bitterness for each other by forcing custody evaluations which are not available in normal custody situations. ${ }^{01}$ Thus, in one case, ${ }^{02}$ a boy of seven had lived with his maternal grandmother since he was three months old, when she removed him from the prison hospital ward where he had been born. His mother was released from prison when the child was about two and a half years old; she lived with him and her mother until the boy was three. At that time the mother married and left to establish a home with her husband. The child was supported by AFDC in his mother's home for two months following her marriage; but his grandmother, unhappy because he was in his mother's home, offered to provide a free home for the boy. An evaluation determined that the grandmother's offer was a resource available for the child's support; AFDC to keep him in his mother's home was terminated and the boy returned to his grandmother. Some years later, the grandmother, now fifty-eight, in poor health, and partially blind, became unable to continue to support the boy and applied for AFDC; the mother thereupon countered with an offer to provide a free home. Investigation of the two homes disclosed that the grandmother hived in a small, two-room apartment

59 E., Sept. 27, 1957. See also $M$., March 20, 1958; $H$., Feb. 20, 1958; $T$., Feb. 15, 1957 (grandmother versus father).

${ }^{60} E$., Sept. 27, 1957.

01 Modification of a custody award is discussed in text accompanying note 25 supra.

$62 T$., March 20, 1958. 
while the mother lived with her husband and their two children in a small house. The Board found that the long-term advantages offered to the boy by his mother and her husband, when coupled with the inother's preferential legal right to custody, indicated that the boy's best interests would be served by placement with the mother even though he would probably suffer a "temporary emotional trauma" at leaving his grandmother. Aid provided for his support in the grandmother's home was therefore discontinued.

Other unique problems were presented by fathers who agreed to provide a free home for their children only if the mother would consent to return as well; and by grandparents who agreed to provide for their grandchildren if the minor mother-daughter would return to the family home. Without exception in the fair hearing appeals, the Social Welfare Board properly refused to permit the withdrawal of AFDC funds to be used to force marital reconciliations. ${ }^{63}$ Nor was the erring daughter required to return home, at least where she was within a year or so of attaiming majority and where it was not entirely clear that her parents' offer was bona fide. ${ }^{64}$ In one case, however, where the mother was sixteen and pregnant a second time, the Board obviously felt it improper to help her remain in "the home of an unmarried woman [her aunt] with dubious sources of unexplained and unreported income." ",65

There are indications in the Fair Hearing Appeals cases that the Staff and Social Welfare Board were uneasy with the offer-of-a-free-home cases. The determination, after all, was uncomfortably close to a child custody award for a program established to deal with child support. It is probably fair to assume that this discontent together with a critical review of the cases in the report of a Cahifornia Senate Committee ${ }^{66}$ investigating the role of the State Social Welfare Board, may have provided the necessary impetus for withdrawal of the Regulation. ${ }^{67}$ The offerof-a-free-home category of appeals cases, though now dormant, provides some important lessons in the workings of a public support program. In administrative law as in courtroom law it is probably fair to assume that the cases appealed are only a fraction of the cases heard; yet it cannot be assumed that the cases not appealed were all fairly or correctly decided.

${ }^{63} H$., Oct. 21, 1955; P., Feb. 25, 1955; cf. V., July 21, 1961 (mother and father were both married to others; county tried to force a reconciliation of the "common law marriage" but was overruled by the Board).

64 T., Dec. 21, 1956; M., Dec. 21, 1956; McC., March 26, 1954.

$65 T$., June 24, 1959.

66 Sweet, The Role of the State Soctad Werfare Board in the Administration of the ANC Prograx IN Califorria 75-78 (1961) (Report to the Senate Fact Finding Committee on Labor and Welfare).

67 For the text of the new regulation, see note 48 supra. 
The appealed case often represents a sharp dissatisfaction with the proceedings below that can be used to illuminate other cases in which the disappointed chient perhaps was not as determined to get justice or as convinced of the rightness of his position. Several such points are suggested in the offer-of-a-free-home appeals. Thus, in many of the cases, the county workers appeared convinced that the mother, having left her husband in Oklahoma, Louisiana, or Mississippi, turned her eyes to California's high welfare payments and decided to come to this state in order to qualify for rehef. In one case, the local workers seemed to beheve that the size of Cahfornia's monthly payment had motivated the break-up: The mother, they claimed, "forsook her spouse for a monetary advantage, looking to the high ANC standards in Cahfornia." fornia requires a one-year residency period of all children not born in the state as a prerequisite to receiving aid ${ }^{69}$ seems not to affect the county's suspicions of these migratory mothers. The offer-of-a-free-home regulations, with their emphasis on the child's financial security, could be used to send the child (and sometimes the mother) back to the state they had left. Thus it could become possible in a limited way for California to reinstate the wall of exclusion against the poor that the United States Supreme Court had destroyed in Edwards v. California, ${ }^{70}$ all in the name of reuniting the family.

Another sore point touched on by many of the cases was the danger that the father's sudden desire to support the child in his own home may have been motivated by the efforts of the district attorney to compel him to support the child in the mother's home. For families living on a restricted budget, it may appear less costly to share the existing resources with a newcomer than to send a monthly payment to the mother. The situation brings out the bitter complaints typical of separated couples; the father suspects that the money he sends will not be spent on the children; the mother fears that the father's promises of support will not actually materialize. The Departmental Manual attempted to solve this problem by suggesting that the worker inquire whether the offer was made in good faith. ${ }^{71}$ The infrequency with which the offers were made by persons not charged with the legal duty of supporting the child, however, raises doubts as to whether the county always fully explored the motivation for the offer.

A related point is the degree to which the person making the offer of a free home was motivated by the fact that the child may have reached an

\footnotetext{
${ }^{68}$ S., Sept. 22, 1961.

69 CAI. WelfaRe \& INST'NS CODE § 11252.

T0 314 U.S. 160 (1941).

71 CaLtFornia Dep't of Soctal Welfare, op. cit. suppra note 48.
} 
age at which he could be useful as a household helper or baby-sitter. A possible analogy to earlier devices for laving children adopted to get them out of publiciy-supported institutions ${ }^{72}$ would be far-fetched; but nagging doubts as to wliether the county evaluated the free home offers rigorousiy from the point of view of the best interests of the child are not easily laid to rest, particularly when several of the Board's decisions admomished the county for inadequate investigation of the offered liome.

In short, the offer-of-a-free-home Regulation provided a vehicie in many cases for county attempts to lower the cost of the public support bill by means other than those designed to encourage "the employment and self-maintenance ${ }^{373}$ of the parents. Although the Board generally arrived at fair results in the cases that were appealed, the effectiveness of such decisions in controlling the county administrators was probably low. The withdrawal of the Regnlation seems to have been the only'meaningful way of reassuring the custodian that the Welfare authorities would no longer force the removal of children from the home because of the availability of a free home elsewhere.

\section{B. Neglect}

The custodian whose children are supported by AFDC may, however; liave reason to fear that the welfare authorities will force the removal of the children on other grounds. Professor tenBroek has spoken of the tendency of the home visits of the welfare caseworker to raise "questions of fitness ... with regard to ... the suitability of the home for the rearing of the children, issues of morahty, extra-marital relations, drinking, and the like. ${ }^{274}$ Referral of child neglect cases from local welfare departments to probation departments may serve to remforce the "inspection" aspects of the caseworker's visits in the minds of the recipients. Low budgets and inadequate staff have made extended casework services for welfare families impracticable except for a few experimental projects. A recent California study dealing with neglected children concludes that for the immediate future, the "referral of child neglect cases from the welfare departments to the probation departments will continue to be a common practice." ${ }^{275}$ Such cases are not difficult to locate in the probation caseload of dependent and neglected children. Thus, in a recent case heard in a metropolitan juvenile court, the following testimony developed:

${ }^{72}$ See tenBroek, Califormia's Dual System of Family Law: Its Origin, Development, and Present Status, 16 StaN. L. Rev. 900, 955-61 (1964).

73 CAL. Wetfare \& INST'NS CODE $\$ 11205$.

74 tenBroek, supra note 44 at 649.

75 National Study Service, Plannzag for the Protection and Care of Negiected Chemoren in Calirornia 39 (Final Report, Aug., 1965) [Hereinafter cited as Natronat StUdy Service]. 
The household was composed of an eighteen-year-old mother and her three children, who ranged in age from two and a half years to eight months. Only the oldest child was supported by AFDC. The mother's husband, father of the two younger children, was absent on duty in the military service. The welfare caseworker, making an unannounced house visit, had found the mother absent from the home and the two older children alone in the house. Upon entering the house accompanied by a neighbor, the caseworker found the house "filthy," one child naked, and mouldy food in the refrigerator. Slie called the police and insisted that the children be taken into protective custody. The children were taken to the county reception center for dependent children, where they remained from Wednesday until Monday, when the detention hearing was held and they were released to the mother pending the juvenile court hearing. At this hearing, held a month later, the mother and father both appeared. The welfare worker testified that the house was "messy but not dirty" and that she had waited for about twenty or thirty minutes before removing the children. The mother's explanation of her absence was that she had been trying to find a baby-sitter to talse care of the older children while she took the baby to see a doctor. She stated that she had never left the children alone before. The father defended his wife, pointing out that she had had a lard time trying to manage for eleven months while he liad been in military service. He seemed bitter towards the worker's actions, and asked the court wliy, if the "welfare lady" really wanted to help his family, she hadn't offered to baby-sit for his wife instead of "calling the cops and bringing us to court?" Upon being told by the judge about the worker's responsibilities under the AFDC program, he stated that they had "gone off" welfare in order to avoid the home visits. He asked whether the court couldn't rely on him to take care of the family; having just ridded his family of the welfare worker, he obviously was not anxious to have her replaced by the probation officer. The court, however, accepted the Probation Department's recommendation that there be some supervision for the children. Accordingly, he made them dependent children of the court and placed them in the family home with provision for a further hearing in ten months.

Figures showing how many AFDC children are referred to probation departments of other protective service agencies as "neglected" children apparently are not available. A recent study in the Minneapolis-St. Paul area, however, indicates that "the educated, econounically independent family is the rare exception among the neglect referrals." ${ }^{\text {" }}$ A two-month

76 Boehm, The Community and the Social Agency Define Neglect, 43 CHWD WeLfare 453, 459 (1964). 
sample of neglect referrals disclosed that, although only three per cent of families in the general population were on public assistance; forty-two per cent of the neglect families were relief recipients. ${ }^{77}$ The Califorma study estimates that a "substantial" number of the 21,264 children who were referred to probation departments from all sources as possible dependent and neglected children during the twelve months ending June 30, 1964 , are located in the AFDC caseload. ${ }^{78}$ Referrals come to probation from the police, schools, local welfare agencies, private agencies, and individuals (parents, neighbors, and attorneys) ${ }^{79}$ The probable causes of the referrals are many and varied. Alameda County gives the following breakdown of its 2,356 referrals for neglected and dependent children in 1964: unfit home situations (952 referrals); no supervision or control (601 referrals); no parent or guardian (356 referrals); parent ill or incapacitated (303 referrals); victims of rape or inolestation ( 65 referrals); protective custody (49 referrals); child unhappy with home situation (20 referrals); and suicide attempts (10 referrals). ${ }^{80}$

A sampling of the cases recently before a metropolitan juvemile court indicates both the range of problems and the depressing sameness of the struggle to solve them with the resources at hand. One case involves three children all under ten years of age caught in the aftermath of divorce: their mother's second husband refused to have them in his home; their father's second wife, after keeping them for some time, was "no longer willing to care for them." The mother was ready to concede permanent legal custody to the father; but he was described as "weak" and under domination by his wife. The children were placed in a foster home; at last indication, the father and stepmother were willing to try it again. In another case, the children were found alone in the home in a condition described by the police officer who took them into custody as "without shoes, hair uncombed, clothing dirty, ragged, torn; unbathed; open sores." The house was covered with "dirt, debris, glass splinters on floor"; the kitchen disclosed a dishpan in stagnant water; a refrigerator empty and filthy; and a stove caked with grease. The father and mother agreed that the children should be placed in a foster home. The mother said she would try to find a job so that she could ultimately reclaim the children. In a third case, the mother and father, both under thirty-five, were unmarried.

77 Ibid.

78 Nattonat Studx SERvice 8-12. It is known that 3,800 of the 20,189 children who had been declared dependent children of the court were being supervised in their own homes by the local welfare department because the family was receiving assistance of some kind. Id. at 44.

70 Id. at 8-12.

801964 Alameda County Probatton Departament, Annual Report 3-4. 
Both have attempted suicide. The child was removed from the home when she was eighteen months old because of the frequent drunken fights of the parents and because the mother left the child alone "more than once during the past six months" in violation of the child neglect standards of the California Probation Officers and the State Department of Social Welfare. ${ }^{81}$ The parents agreed that they were unable to care for their daughter, and a foster home placement was arranged.

Despite the wide use of foster home placements in Cahifornia, ${ }^{82}$ these cases are not typical in using such placement in neglect cases. Of the 20,189 dependent children of the court being supervised by probation departments as of December 31,1963,11,000 were under supervision in their own homes and only 8,175 were in foster homes or the homes of relatives. ${ }^{83}$ The problem of neglect is a specialized problem of child custody; perhaps it is fair to say that the problem is largely one of developing the resources and facilities needed to provide physical and emotional security to neglected children in their own homes. It is now becoming widely recognized that "because of the vital importance of a child's own parents, the primary efforts of any community should be to preserve them for him; to assist them in carrying their responsibilities successfully, and to prevent family breakdown., ${ }^{84}$

A special problem of neglect for poverty-stricken families appears to be that, because of the differences in socio-economic class attitudes toward parental competence, children may be removed from the home too soon. ${ }^{85}$ Reinhart and Elmer, in their study of the abused child, noted that "in view of the gravity of the data at hand about a large proportion of the patients, it was anticipated that the follow-up study would reveal extreme pathology among the families. While this has been true of some family groups, a few others have shown warmth, good capacity for child-

81 Nationat STUdy Service 5-6.

82 "It is estimated that there were approximately 21,000 children under agency supervision in licensed foster loomes in Califorma in June 1964." Nationac Study Service 66. This figure does not include children placed directly by their parents. "It is estimated that the number so placed may be 10 per cent as many as placed by agencies." Id. at 66 n.30.

83 NATIONAI STUdy SERvice 44 (861 children were in institutions).

84 Id. at 23 .

85 See Polier, The Invisible Legal Rights of the Poor, 12 CHIDRen 215, 218 (1965): "mothers in the aid to families with dependent children (AFDC) program receive on the average less than $\$ 1$ a day for each child. If we find that the home is inadequate, that the mother is unable to cope with the problems of so many children, we remove the child to the lome of a stranger or series of strangers, paying from public funds up to $\$ 7$ a day for the child's care. If the child is removed to an institution, the institution is paid up to $\$ 14$ a day. Fimally, if the child becomes emotionally disturbed, payments from public funds may range froin $\$ 10$ to $\$ 25$ a day. Thus, the further the child is removed from his family, the more we are ready to pay for his support." 
rearing, and an unexpected degree of integration." the mother "has failed to provide a moral environment in that during the last six years, she has had six illegitimate pregnancies" may overlook qualities that make her a good mother to all the children. The important question is how such behavior influences the child's development, ${ }^{87}$ since parental deficiencies may be balanced by parental strengths. At the same time, however, children should not be allowed to remain in homes under serious conditions of neglect merely because foster-care facilities are costly and madequate. ${ }^{88}$ The problem is how a caseworker can be trained to appraise family situations much different from those his own experience had led him to expect and in a way that will assume maximum protection for the child.

Even with the best casework services available, however, "the only way adequately to protect some children will be to remove them promptly from the care of their parents." ${ }^{\prime 89}$ Here the placement problem becomes critical; perhaps more critical for the poverty families than for the wellto-do. A recent juvenile court case illustrates one aspect of the problem. a ten-year-old boy who liad been supported by AFDC funds since birth was taken into protective custody following a beating by his stepfather. It was discovered that he had serious beliavior problems that made foster placement inappropriate. Twenty institutions were approached as possible placements for the boy; none of them were available. He was rejected on a variety of grounds: He was either too young or too old; he did not meet the religious membership tests of some of the private institutions; he was too retarded for some, too bright for others. After six months of holding the boy at Juvenile Hall, the Probation Department was forced to report to the juvemile court that "there are currently no placement possibilities."

\footnotetext{
${ }^{86}$ Reinhart \& Elmer, The Abused Child, A.M.A.J., April 27, 1964, pp. 358, 361.

87 Cf. Ashwell v. Ashwell, 135 Cal. App. 2d 211, 286 P.2d 983 (1955), where the mother, her four children under six years of age, and her illegitimate baby were all living with the baby's father while waiting for her divorce to become final. The court, reversing the trial court's change of custody of the four children to their father, said: "It is proper to bear in mind, as these things are being considered, that in determining where custody of children shall he the courts are not engaged in a disciplinary action to punish parents for their shortcomings as individuals nor to reward the unoffending parent for any wrong suffered by the sins of the other.... The prime question is, what is the effect upon the lives of the children and what will be the effect of a modified decree that disturbs their settled life and compels them to make adjustments to a life with strangers. In view of the tender ages of these children we think that the conduct of the mother as described in the testimony was at the time this change was ordered having no possible bad effect upon them. They were too young." Id. at 217, 286 P.2d at 987. But see Currin v. Currin, 125 Cal. App. 2d 644, 271 P.2d 61 (1954), where the court demied the mother custody in a situation where the mother's conduct was characterized as "indiscriminate, profligate and shameless." $I d$. at $650,27 I$ P.2d at 65.
}

88 See Polier, supra note 85, at 219.

89 National Study Service 23. 
The Department nevertheless recommended against returning the boy to his home; the judge agreed that attempts at placement should be contimued, but sent the boy home while the attempts were being pursued. Another case disclosed that a juvenile court in a neighboring state had deprived the mother of her two children; aged five and six, because she frequently beat them and left them unattended for prolonged periods. The children were placed in the custody of a maternal aunt and uncle and funds were supplied to help with their support. When the children were ten and eleven, the mother married a man recently paroled after serving a criminal sentence and asked that the children be returned to her home. Although her adjustment continued to be borderline, the children were returned to maintain the family home and because "the children need their mother.". When the family moved to California, no records were forwarded and no supervision was maintained. When the children were twelve and thirteen, the younger, a girl, complained to her school counsellor that for the past two years she had been molested repeatedly by her stepfather. On further investigation, the boy reported that the stepfather had subjected him regularly to experiences of sodomy and fellatio. The juvenile court placed the children in a local foster home, and they were later permitted to return to their aunt and uncle. The original decision to return these children to their mother's home appears to have substantially contributed to the disruption of their lives.

Adoption, if viewed as a permanent solution to the placement problem, discloses sharp differences between white and nonwhite poverty groups. There seems no longer to be any doubt that minority-group children are not acceptable for adoption because of the practical impossibility of locating adoptive homes. ${ }^{90}$ The lack of early protective services for these children is directly related to the adoption problem: California figures show that ninety per cent of all adoptive placements are made before the child is one year old. ${ }^{91}$ The difficulties of placing the older child for adoption even under the best circumstances simply means that the problem is heightened for minority groups because their children are not made available for adoption at an early age.

Fimally, the recent emergence of the "Battered Child Syndrome" provides an aggravated microcosin in which the more general problems of the child custody law of the poor are reflected. Reports from the medical profession indicate that "many loold the sentiment that private patients

$90 \mathrm{Id}$. at $81-82$; Polier, supra note 85 , at 216-17.

91 NATIONAL STUdy SeRvice 81.

92 For an excellent beginning to a forthcoming comprehensive series of articles on this problem, see McCoid, The Battered Child and Other Assatlts Upon the Family: Part One, 50 MINN. I. REv. 1 (1965). 
should be managed differently from clinic patients. Pressure is strong to refer the latter to court almost in summary procedure, even before identifying information for family inembers can be obtained." ${ }^{93}$ Often a physician will not report a private patient to police authorities, but will attempt to handle the situation himself. Children who receive private inedical care are thus infrequently reported in the medical hterature. The children of the poor, on the other hand, come to the attention of authorities through social welfare channels in which the reporting is done by welfare workers, police, and schools. This public scrutiny may result in more adequate protection for children of the poor: a sort of inverse discrimination. However, the reports even on poverty-stricken families tend to be limited to physical abuse. Psychological abuse is rarely a cause for the removal of a child from his home. Nevertheless; probation officers are pointing to a "Beverly Hills Syndrome," in whicl the child who is raised in economically favorable circumstances may be unwanted, uncared for, and rarely attended except by hired help. Problems of these children may become known to public authorities only through petty dehinquencies such as alcohohism, promiscuity, motor vehicle violations, and property destruction. ${ }^{94}$

\section{CONCLUSION}

Child custody problems are not easily resolved. One of the primary duties of the law is to provide a procedure for handling custody matters so that the best available knowledge about the effect on a particular child of the dissolution of his family can be brought to bear on the solution of the problem. This task is not discharged by simply calling for equal treatment of the children of rich and poor families, for under the present law the ricli clild may fare as badly as the poor. The entire structure is in need of review.

Nor is it enough to place the entire effort behind proposals designed to keep families together, tempting though that goal may be. This is not an area in which success can be measured only in terms of the number of families who are reconciled. Some families should not stay together. For these fanilies, the law inust recognize that divorce is necessary and should be available to decently end the marriage, even for those unable to afford a lawyer. Divorce will not be abolished; and even if it were, family dissolution would not thereby be ended..$^{95}$ Moreover, as the anthro-

93 Reinhart \& EImer, The Abused Child, A.M.A.J., April 27, 1964, pp. 358, 359.

94 The Beverly Hills Syndrome, unpublished Proceedings of the Conference on Probation and the Law sponsored by the Department of Health and Welfare, State of California, San Francisco, April, 1963.

95 See Rheinstein, Divorce and the Law in Germany: A Review, 65 American J. of Sociology 489 (1960). 
pologist Paul Bohannan has pointed out, divorce does not end family life: It ends only married life. ${ }^{96}$ The divorced spouses are still parents and often they maintain an active kinship relation through the children, not only with each other but also with the children's new stepparents. Yet the law has rarely considered, let alone provided for; the family problems that follow after divorce.

As an integral part of divorce, a sensible custody plan must be worked out to prevent the spouses from using the children as battering-rams against each other. Much of the anguish that follows a bitter divorce could be averted if the law would use behavioral scientists in ways more in keeping with their experience and training. ${ }^{97}$ Too often the psychiatrist called upon to aid the court in awarding custody is looked upon as an individual who gathers facts about the personal lives and emotional state of each parent to determine which is unfit or which will offer the best home. The determination is difficult if viewed in this perspective. The psychiatrist sees two parents in conflict who may be utilizing the custody determination as a means of retaliating against each other. If we perceive that custody disputes often result from conflict between parents who are originally hurt by the behavior of their inates and, in turn, convert this hurt into anger followed by retaliation, then the essential problem in such custody turmoils is to help each parent resolve aspects of his original conflict so that both will begin to work at what would be the best interests of the child rather than personal satisfaction. Reasonable parents in this situation who are acting nnreasonably towards each other may be helped to resolve their differences about the child despite the divorce and allow an integrated solution to occur.

If providing short-term counseling for the parents within the court setting will help to attain this goal, then counseling should be provided at public expense through the estabhshment of family courts with experienced and trained personnel to offer help to the family after the divorce is granted and so long as the child is under the jurisdiction of the court. If sufficient time is allowed to begin work with each parent alone or together, the hife of the child may be less disrupted by continued battles and repeated petitions for modification.

\footnotetext{
96 Bohannan, Notes on the Ethnography of Divorce Among the American Middle Classes, Nov. 19, 1965 (Unpublished, read at the American Association of Anthropologists Meetings).

${ }^{97}$ See also Philips, Mental Hygiene, Divorce and the Law, 3 J. Fasmur L. 63, 70 (1963).
} 